\title{
SURVEI PENGETAHUAN MASAYARAKAT TENTANG TANAMAN OBAT KELUARGA PUSKESMAS AIR TABIT
}

\author{
Erlindawati, $M$.
}

\begin{abstract}
ABSTRAK
Tanaman Obat Keluarga (TOGA) merupakan salah satu alternatif pengobatan yang telah lama dilakukan oleh masyarakat Indonesia secara tradisional. Keberhasilan pemanfaatan TOGA ini sangat dipengaruhi oleh pengetahuan masyarakat mengenai manfaat dari setiap jenis tanaman yang berkhasiat obat terutama tanaman obat yang telah diteliti secara empiris. Selain itu juga dipengaruhi oleh cara penggunaan masing-masing tanaman obat untuk berbagai penyakit yang berbeda.

Penelitian ini bertujuan untuk mengetahui gambaran pengetahuan masyarakat tentang pemanfaatan Tanaman Obat Keluarga di wilayah kerja Puskesmas Air Tabit Kota Payakumbuh .

Metode penelitian ini adalah deskriptif, dengan sampel sebanyak 35 responden yang diambil dengan teknik sampel acak sederhana. Pengumpulan data dilakukan secara wawancara langsung kepada responden dengan Instrument penelitian yang digunakan kuesioner

Dari hasil penelitian didapatkan bahwa pengetahuan responden tentang nama dan keguanaan obat tadisional masih rendah sebesar ( $11,4 \%$ ), Hanya ( $22,5 \%$ ) responden yang mendapatkan informasi tanaman obat keluarga dari petugas kesehatan dan hampir separoh $(47,5 \%)$ responden mendapatkan informasi secara turun temurun

Untuk meningkatkan pengetahuan masyarakat dan pemanfaatan Tanaman obat keluarga Puskesmas harus meningkatkan frekwensi dan intensitas penyuluhan Tanaman obat keluarga serta menyediakan informasi berupa leaflet, poster, brosur dan spanduk tanaman Obat keluarga di Puskesmas Air Tabit Disamping itu Puskesmas juga harus mengoptimalkan Toga Model yang ada di Puskesmas.

Tanaman obat keluarga (disingkat TOGA) adalah tanaman hasil budidaya rumahan yang berkhasiat sebagai obat. Taman obat keluarga pada hakekatnya adalah sebidang tanah, baik di halaman rumah, kebun ataupun ladang yang digunakan untuk membudidayakan tanaman yang berkhasiat sebagai obat dalam rangka memenuhi keperluan keluarga akan obat-obatan. Kebun tanaman obat atau bahan obat dan selanjutnya dapat disalurkan kepada masyarakat, khususnya obat yang berasal dari tumbuh-tumbuhan. Budidaya tanaman obat untuk keluarga (TOGA) dapat memacu usaha kecil dan menengah di bidang obat-obatan herbal sekalipun dilakukan secara individual. Setiap keluarga dapat membudidayakan tanaman obat secara mandiri dan memanfaatkannya, sehingga akan terwujud prinsip kemandirian dalam pengobatan keluarga.
\end{abstract}

Kata kunci: Zeolit, minyak jelantah, adsorpsi

\section{PENDAHULUAN}

Dewasa ini pengobatan secara alami menggunakan tanaman obat sedang menjadi trend di tengah masyarakat kita. Selain lingkungan menjadi hijau, tanaman obat bisa membantu kebutuhan ekonomi keluarga. Tidak hanya untuk tanaman obat, tapi juga untuk tanaman hias, bunga atau buah-buahan. Bahkan beberapa dari warga mengolah tanaman obat menjadi jamu. Mulai jamu dalam bentuk cairan dan langsung minum atau dikemas dalam bentuk bubuk. Inilah yang dimaksud mempunyai manfaat ganda. Karena hasilnya dapat menambah ekonomi keluarga.

Toga adalah singkatan dari tanaman obat keluarga. Taman obat keluarga pada hakekatnya sebidang tanah baik di halaman rumah, kebun ataupun ladang yang digunakan untuk membudidayakan tanaman yang berkhasiat sebagai obat dalam rangka memenuhi keperluan keluarga akan obat-obatan. Kebun tanaman obat atau bahan obat dan selanjutnya dapat disalurkan kepada masyarakat, khususnya obat yang berasal dari tumbuh-tumbuhan. Salah satu fungsi Toga adalah sebagai sarana untuk mendekatkan tanaman obat kepada upaya-upaya kesehatan masyarakat yang antara lain meliputi:

1. Upaya preventif (pencegahan)

2. Upaya promotif (meningkatkan derajat kesehatan)

3. Upaya kuratif (penyembuhan penyakit)

Selama ini belum tersedia data tentang seberapa besar pengetahuan masyarakat tentang pemanfaatan tanaman obat keluarga (Toga) 
diwilayah kerja Puskesmas Air Tabit. Untuk menjawab pertanyaan tersebut diatas, penulis tertarik melakuka penelitian tentang Pengetahuan masyarakat tentang pemanfaatan obat keluarga (TOGA) di wilayah kerja Puskesmas Air Tabit.

\section{METODOLOGI PENELITIAN}

Desain Penelitian

Jenis penelitian Quick Survey. Penelitian ini bertujuan melihat pengetahuan masyarakat tentang Pemanfaatan Tanaman Obat Keluarga (TOGA) di Wilayah Kerja Puskesmas Air Tabit penelitian yang dilakukan oleh petugas di Puskesmas Air Tabit

Tempat penelitian

Penelitian dilakukan di Puskesmas Air Tabit

Populasi dan Sampel

Populasi

Populasi dalam penelitian ini adalah seluruh pasien yang berkunjung ke Puskesmas Air Tabit yang mendapatkan pelayanan / pengobatan di Puskesmas Air Tabit dengan Rata - rata Kunjungan per bulan sebesar 1.184 orang

\section{Sampel}

Pengambilan sampel menggunakan Teknik Non Systematic Random Sampling. Sampel diambil berjumlah 35 responden dengan kriteria:

- Bersedia jadi responden

- Bisa tulis baca

- Sehat jasmani dan rohani

Pengumpulan Data

Pengumpulan data dilaksanakan dengan cara wawancara untuk mendapatkan informasi yang dibutuhkan oleh peneliti. Data hasil wawancara diolah dan dianalisa secara manual.

Teknik Pengolahan dan analisa data

Cara pengolahan data

Setelah data terkumpul data diolah secara manual. Dilakukan langkah - langkah dalam pengumpulan data sebagai berikut:

\section{a. Pemeriksaan Data (Editing )}

Setelah Kuisioner dikumpulkan oleh Responden maka setiap Kuisioner diperiksa secara teliti apakah sudah diisi dengan benar dan semua item telah dijawab oleh Responden.

\section{b. Pengkodean ( Coding )}

Memberikan kode pada setiap Kuisioner yang telah terkumpul untuk memudahkan dalam mengolah data

c. Memproses data ( Processing )

Setelah semua Kuisioner terisi penuh dan benar serta sudah dilakukan pengkodean, maka langkah selanjutnya adalah memproses data. Pemrosesan data dilakukan dengan cara mengentry data dengan menggunakan program SPSS

d. Pembersihan Data ( Cleaning)

Kegiatan ini bertujuan untuk pengecekan kembali data yang sudah di-Entry apakah masih ada kesalahan data .

Analisa data

Analisa Univariat.

Menurut (Hastono,2006,p63) Tujuan analisa univariat adalah untuk menjelaskan karakteristik masing - masing variabel yang diteliti. Lebih lanjut dijelaskan bahwa: Fungsi analisis sebetulnya adalah menyederhanakan / Meringkas kumpulan data hasil pengukuran sedemikian rupa sehingga kumpulan data tersebut berubah menjadi informasi yang berguna.

\section{HASIL DAN PEMBAHASAN}

\section{Analisa Univariat}

Tabel 1. Distribusi Frekwensi ketersediaan Tanaman obat keluarga di rumah responden Di wilayah kerja Puskesmas Air Tabit

\begin{tabular}{|c|c|c|c|}
\hline No & Variabel & Jumlah & Persentase \\
\hline 1 & $\begin{array}{c}\text { Terdapat toga di } \\
\text { rumah }\end{array}$ & 25 & $71,4 \%$ \\
\hline 2 & $\begin{array}{c}\text { Tidak terdapat } \\
\text { toga dirumah }\end{array}$ & 10 & $28,6 \%$ \\
\hline \multicolumn{2}{|c|}{ Jumlah } & 35 & $100 \%$ \\
\hline
\end{tabular}

Dari hasil tabel diatas diperoleh data bahwa lebih dari separo responden $(71,4 \%)$ yang menyatakan memiliki tanaman obat keluarga di rumah. Tanaman obat yang ada di rumah bervariasi ada yang ditanam di Pot dan ada yang ditanam di pekaranangan rumah. Responden yang tidak memiliki tanaman obat keluarga di 
rumah disebabka oleh: tidak memiliki lahan untuk menanam dan sebagian lagi berpendapat tidak memiliki waktu untuk mengurus tanaman obat keluarga di rumah

Tabel 2. Distribusi Frekwensi Pengetahuan Responden tentang nama obat tradisional dan kegunaan nya Di Wilayah Puskesmas Air Tabit

\begin{tabular}{|c|c|c|c|}
\hline No & Variabel & Jumlah & Persentase \\
\hline 1 & Baik & 4 & $11,4 \%$ \\
\hline 2 & Tidak Baik & 31 & $88,6 \%$ \\
\hline \multicolumn{2}{|c|}{ Jumlah } & 35 & $100 \%$ \\
\hline
\end{tabular}

Dari hasil tabel diatas diperoleh data bahwa hanya 4 responden $(11,4 \%)$ Yang mengetahui 10 jenis tanaman Obat Tradisional dan manfaatnya dengan benar.

Tabel 3. Distribusi Frekwensi Penggunaan Toga oleh Responden Di Wilayah Puskesmas Air Tabit

\begin{tabular}{|c|c|c|c|}
\hline No & Variabel & Jumlah & Persentase \\
\hline 1 & $\begin{array}{c}\text { Menggunakan } \\
\text { Toga }\end{array}$ & 26 & $74,2 \%$ \\
\hline 2 & $\begin{array}{c}\text { Tidak } \\
\text { Menggunakan } \\
\text { Toga }\end{array}$ & 9 & $25,8 \%$ \\
\hline \multicolumn{2}{|c|}{ Jumlah } & 35 & $100 \%$ \\
\hline
\end{tabular}

Dari hasil tabel diatas diperoleh data bahwa lebih dari separo $(74,2 \%)$ responden ada menggunakan tanaman obat keluarga jika mengalami sakit Menurut peneliti hal ini kemungkinan disebabkan oleh: Tanaman obat keluarga dimanfaatkan oleh keluarga sebagi pertolongan pertama sebelum pasien berkunjung ke Puskesmas atau Klinik pengobatan .

Tabel 4. Distribusi Frekwensi alasan responden tidak menggunakan Toga Di ilayah KerjaPuskesmas Air Tabit

\begin{tabular}{|c|c|c|c|}
\hline No & Variabel & Jumlah & Persentase \\
\hline 1 & $\begin{array}{c}\text { Tidak memiliki } \\
\text { Toga dirumah }\end{array}$ & 3 & $33,4 \%$ \\
\hline 2 & $\begin{array}{c}\text { Toga Sulit } \\
\text { didapat }\end{array}$ & 2 & $22,2 \%$ \\
\hline 3 & Tidak Biasa & 1 & $11,1, \%$ \\
\hline
\end{tabular}

\begin{tabular}{|c|c|c|c|}
\hline & $\begin{array}{c}\text { menggunakan } \\
\text { Toga }\end{array}$ & & \\
\hline 4 & $\begin{array}{l}\text { Repot membuat } \\
\text { ramuan Toga }\end{array}$ & 1 & $11,1, \%$ \\
\hline 5 & $\begin{array}{c}\text { Sudah Biasa jika } \\
\text { sakit langsung ke } \\
\text { Puskesmas }\end{array}$ & 1 & $11,1, \%$ \\
\hline 6 & $\begin{array}{c}\text { Reaksi Toga } \\
\text { Lebih lambat } \\
\text { dibandingkan } \\
\text { dengan obat } \\
\text { medis }\end{array}$ & 1 & $11,1, \%$ \\
\hline & Jumlah & 9 & $100 \%$ \\
\hline
\end{tabular}

Dari hasil tabel diatas diperoleh data bahwa alasan responden tidak menggunakan Toga sebesar 33,3\% disebabkan karena keluarga tidak memiliki Tanaman Obat Keluarga di Rumah selanjutnya 22,2\% disebabkan karena Tanaman Obat Keluarga Sulit Didapat. Alasan lain yang disampaikan oleh responden adalah: Tidak biasa menggunakan Toga, Repot Membuat ramuan Toga, Sudah Biasa jika sakit langsung ke Puskesmas dan menurut responden Reaksi Toga lebih lambat jika dibandingkan dengan obat medis

Tabel 5. Distribusi Frekwensi sumber informasi responden tentang Toga Di Wilayah KerjaPuskesmas Air Tabit

\begin{tabular}{|c|c|c|c|}
\hline No & Variabel & Jumlah & Persentase \\
\hline 1 & Terun temurun & 19 & $47,5 \%$ \\
\hline 2 & $\begin{array}{c}\text { Tenaga } \\
\text { Kesehatan }\end{array}$ & 9 & $22,5 \%$ \\
\hline 3 & $\begin{array}{c}\text { Dukun } \\
\text { Media } \\
\text { Elektronik }\end{array}$ & 5 & $10 \%$ \\
\hline 5 & Teman & 3 & $7,5 \%$ \\
\hline \multicolumn{2}{|c|}{ Jumlah } & 40 & $100 \%$ \\
\hline
\end{tabular}

Dari hasil tabel diatas diperoleh data hampir separoh (47,5\%) responden mendapatkan informasi tentang tanaman Obat Keluarga (TOGA) secara turun temurun. Selanjutnya 22,5 $\%$ mendapatkan informasi tentang Tanaman Obat Keluarga dari Petugas Kesehatan. Sumber Informasi lain yang memberikan informasi 
tentang tanaman obat keluarga diperoleh dari: Media Elektronik 12,5 \%, dari dukun $10 \%$ dan dari teman sebesar 7,5\%

Tabel 6. Distribusi Frekwensi Pendapat Responden tentang Khasiat Toga dengan obat kimia Di Wilayah Kerja Puskesmas Air Tabit

\begin{tabular}{|c|c|c|c|}
\hline No & Variabel & Jumlah & Persentase \\
\hline 1 & $\begin{array}{c}\text { Sama } \\
\text { Khasiatnya }\end{array}$ & 14 & $40 \%$ \\
\hline 2 & $\begin{array}{c}\text { Tidak Sama } \\
\text { Khasiatnya }\end{array}$ & 21 & $60 \%$ \\
\hline \multicolumn{2}{|c|}{ Jumlah } & 35 & $100 \%$ \\
\hline
\end{tabular}

Dari hasil tabel diatas diperoleh data dua pertiga $(60 \%)$ responden yang menyatakan bahwa khasiat Tanaman Obat Keluarga Tidak sama dengan Khasiat obat kimia (Pengobatan yang diberikan di Puskesmas/Rumah Sakit) Menurut responden khasiat obat kimia (Pengobatan yang diberikan di Puskesmas / Rumah Sakit) lebih cepat reaksinya jika dibandingkan dengan khasiat tanaman Obat Keluarga (TOGA)

\section{KESIMPULAN}

Berdasarkan hasil pembahasan yang telah dilakukan, dapat disimpulkan:

Tingkat pengetahuan Responden terhadap Nama dan Manfaat obat tradisional masih rendah sebesar $(11,4 \%)$ dan hampir separo (47,5\%) Responden memperoleh pengetahuan tanaman obat tradisional dari dukun dan hanya $(22,5 \%)$ Responden yang memperoleh informasi dari Tenaga Kesehatan.
Dari hasil penelitian didapatkan data bahwa lebih dari separo $(71,4 \%)$ responden menyatakan terdapat tanaman obat keluarga di rumah dan lebih dari separo $(74,2 \%)$ Responden ada menggunakan tanaman obat keluarga Jika sakit

Dari hasil penelitian didapatkan data lebih dari separo $(60 \%)$ responden menyatakan bahwa kahsiat Tanaman Obat Keluarga (TOGA) tidak sama dengan khasiat obat Kimia (obat yang di berikan di Puskesmas dan Rumah Sakit menurut responden obat kimai memiliki reaksi yang lebih cepat jika dibandingkan dengan tanaman obat Keluarga (Toga)

Tingkat pengetahuan Responden terhadap Nama dan Manfaat obat tradisional masih rendah sebesar $(11,4 \%)$ dan hampir separo (47,5\%) Responden memperoleh pengetahuan tanaman obat tradisional dari dukun dan hanya (22,5\%) Responden yang memperoleh informasi dari Tenaga Kesehatan

Dari hasil penelitian didapatkan data bahwa lebih dari separo $(71,4 \%)$ responden menyatakan terdapat tanaman obat keluarga di rumah dan lebih dari separo $(74,2 \%)$ Responden ada menggunakan tanaman obat keluarga Jika sakit

Dari hasil penelitian didapatkan data lebih dari separo $(60 \%)$ responden menyatakan bahwa kahsiat Tanaman Obat Keluarga (TOGA) tidak sama dengan khasiat obat Kimia (obat yang di berikan di Puskesmas dan Rumah Sakit) menurut responden obat kimai memiliki reaksi yang lebih cepat jika dibandingkan dengan tanaman obat Keluarga (Toga) 